\title{
An Irrigation Scheduling Model for Snap Bean
}

\author{
Doyle A. Smittle', W. Lamar Dickens', and James R. Stansell ${ }^{2}$ \\ Coastal Plain Experiment Station, University of Georgia, Tifton, GA 31793 \\ Additional index words. soil water tension, pan evaporation, nitrogen fertilization, Phaseolus vulgaris
}

\begin{abstract}
An irrigation scheduling model for snap bean (Phaseolus vulgaris L.) was developed and validated. The irrigation scheduling model is represented by the equation: $12.7(\mathrm{i}-4) \times 0.5 \mathrm{ASW}=\mathrm{D}_{\mathrm{i}-1}+[\mathbf{E}(0.31+0.01 \mathrm{i})-\mathrm{P}$ $-\mathrm{I}]_{i}$, where crop age is $i$; effective root depth is $12.7(\mathrm{i}-4)$ with a maximum of $400 \mathrm{~mm}$; usable water $\left(\mathrm{cm}^{3} \cdot \mathrm{cm}^{3}\right.$ of soil) is $0.5 \mathrm{ASW}$, deficit on the previous day is $\mathrm{D}_{\mathrm{i}-1}$; evapotranspiration is pan evaporation (E) times $0.31+0.01 \mathrm{i}$; rainfall $(\mathrm{mm})$ is $P$, and irrigation $(\mathrm{mm})$ is $I$. The model was validated using a line source irrigation system with irrigation depths ranging from $3 \%$ to $145 \%$ of tbe model rate in 1985 and from $4 \%$ to $180 \%$ of the model rate in 1986. Nitrogen fertilization rates ranged from $50 \%$ to $150 \%$ of the recommended rate both years. Marketable pod yields increased as irrigation rate increased in 1985. Irrigation at $4 \%, 44 \%, 65 \%, 80 \%, 150 \%$, and $180 \%$ of the model rate produced yields that were $4 \%, 39 \%, 71 \%, 85 \%, 92 \%$, and $55 \%$ as great as yields with the model rate in 1986. Marketable pod yields increased as $N$ rate increased when irrigation was applied at $80 \%, 100 \%$, or $150 \%$ of the model rate in 1986, but pod yields varied less with $N$ rate when irrigation was applied at $4 \%, 44 \%, 65 \%$, or $180 \%$ of the model.
\end{abstract}

Snap beans have a relatively shallow rooting depth (Bruce et al., 1980; Keisling et al., 1975) and are more responsive to frequent irrigations than are deep-rooted crops (Bruce et al., 1980; Maurer et al., 1969; Smittle, 1974; Smittle, 1976; Stansell and Smittle, 1980). Most researchers agree that irrigation should be applied before more than $50 \%$ of the available water is depleted from the root zone (Bruce et al., 1980; Hansen et al., 1980; Mack and Varseveld, 1982; Maurer et al., 1969; Smittle, 1976; Vittum and Flocker, 1967). Maurer et al. (1969) concluded that water should be applied when $22 \%$ of the available water was depleted, but Mack and Varseveld (1982) reported that water should be applied when $40 \%$ to $45 \%$ of the available water was depleted. The rooting zone is not uniformly permeated by roots (Portas, 1968) and is a dynamic rather than a static system. Therefore, the fraction of the available soil water depleted before yield reductions are observed would be dependent on the depth at which soil water is measured and upon the rooting depth of the crop. Hansen et al. (1980) indicated that the root system expanded at the rate of 12 to 15 $\mathrm{mm} \cdot \mathrm{day}^{-1}$ under good growing conditions unless soil conditions impeded root growth. Soils in the southeast normally do not allow crops to root as deeply as do soils of the western United States (Bruce et al., 1980). Determination of the effective rooting volume is essential to the development of an effective irrigation program.

Soil-, plant-, and climatic-based measurements have been used to schedule irrigation. These methods have been reviewed by Haise and Hagan (1967), Hansen et al. (1980), Stegman et al. (1980), and Vittum and Flocker (1967). Ease of use and availability of measurement data are important criteria in the selection of a method to schedule irrigations. Climate-based methods of estimating evapotranspiration (ET) have been used frequently in irrigation scheduling models (Haise and Hagan, 1967; Hansen et al., 1980; Stegman et al., 1980), but calibration for the crop and local climatic conditions often has been required. The climate-based methods of estimating evapotranspiration usually

Received for publication 16 Mar. 1989. Supported by state and Hatch Act funds allocated to the Georgia Agricultural Experiment Stations and grant funds from the Richard King Mellon Foundation. The cost of publishing this paper was defrayed in part by the payment of page charges. Under postal regulations, this paper therefore must be hereby marked advertisement solely to indicate this fact.

'Dcpt. of Horticulture.

${ }^{2}$ Dept. of Agricultural Engineering. incorporate measurements of air temperature, air movement, solar radiation, and relative humidity (Haise and Hagan, 1967). Pan evaporation is responsive to these climatic conditions and has been used to estimate evapotranspiration (Jensen and Middleton, 1970; Keisling et al., 1975; Singh, 1989; Smittle, 1974; Smittle, 1976).

This research describes the development and validation of an irrigation scheduling model for snap beans. The model uses pan evaporation with a continuous crop factor function to estimate ET and a dynamic root depth function to schedule irrigation.

\section{Materials and Methods}

Model development. The irrigation scheduling model uses the water balance technique described by Stegman et al. (1980). This balance for irrigation scheduling may be computed as: A $=D_{i-1}+(E T-P-I)$, where $A_{i}$ is the allowable soil water depletion on day $i ; D_{i}-{ }_{1}$ is the soil water depletion on day $i-1$; ET is the estimated evapotranspiration on day $\mathrm{i}$; $\mathrm{P}$ is the precipitation on day $\mathrm{i}$, and $\mathrm{I}$ is the irrigation on day $\mathrm{i}$.

The allowable soil water depletion is a function of effective root (water extraction) depth, water retention characteristics of the soil, and crop sensitivity to water stress. The root system of most crops expands at a rate of 12 to $15 \mathrm{~mm} \cdot \mathrm{day}^{-1}$ (Hansen et al., 1980). Water extraction by snap bean was restricted to the upper $400 \mathrm{~mm}$ of the soil profile (Bruce et al., 1980; Smittle and Johnson, 1982; Stansell and Smittle, 1980). For the model, we assumed a seeding depth of $25 \mathrm{~mm}, 6$ days for significant radicle emergence, a root expansion rate of $12.7 \mathrm{~mm} \cdot \mathrm{day}^{-1}$, and a maximum root depth of $400 \mathrm{~mm}$. Root depth on day $\mathrm{i}$ can be computed as: $R_{i}=12.7(i-4)$, where $R_{i}$ does not exceed $400 \mathrm{~mm}$ except for deep soils (Bonanno and Mack, 1983a, $1983 \mathrm{~b}$ ) or may be $<400 \mathrm{~mm}$ if tillage pans or other soil factors restrict root growth (Bruce et al., 1980; Smittle and Johnson, 1982).

The water retention characteristics vary from 0.02 to 0.23 $\mathrm{cm}^{3} \cdot \mathrm{cm}^{-3}$ among soil texture classes with available water-holding capacities generally increasing as soil particle size becomes smaller (Hansen et al., 1980; Stegman, 1980). The upper retention limit (field capacity) is normally measured after 2 to 4 days of drainage. Hansen et al. (1980) stated that water use by crops at soil water contents above field capacity was substantial under frequent irrigation; therefore, depletion of $50 \%$ of the available soil water (ASW) was allowed. The ASW of the Tifton loamy sand (Plinthitic Paleudult; fine loamy, siliceous, thermic) 
soil of this experiment was $0.1 \mathrm{~cm}$ per $\mathrm{cm}$ of soil depth. The allowable depletion during root zone expansion can be computed as: $\mathrm{A}_{\mathrm{i}}=\mathrm{R}_{\mathrm{i}} \times 0.5 \mathrm{ASW}$.

Daily water use (ET) was computed using the procedure of Jensen and Middleton (1970). Daily crop factor (K) values were developed from water use and pan evaporation equations reported by Stansell and Smittle (1980) for snap beans irrigated at $25 \mathrm{kPa}$ of soil water tension. In these experiments, pan evaporation (E) averaged $4.88 \mathrm{~mm} \cdot \mathrm{day}^{-1}$ and daily ET was computed as $1.52+0.05$ i. Daily crop factor values of $(\mathrm{K}=\mathrm{ET} /$ E) are computed as: $K=0.31+0.01$. Crop factor values computed by this equation ranged from 0.32 to 0.95 for the 64day growing season for the snap bean. The range of these values is similar to values used earlier (Smittle, 1976). Daily water use (ET) was computed as: $\mathrm{ET}=\mathrm{E}(0.31+0.01 \mathrm{i})$.

The irrigation scheduling model is represented by the equation: $12.7(\mathrm{i}-4) \times 0.5 \mathrm{ASW}=\mathrm{D}_{\mathrm{i}_{1}}+[\mathrm{E}(0.31+0.01 \mathrm{i})-$ $\mathrm{P}-\mathrm{I})]_{\mathrm{i}}$. For computational ease and record keeping, this equation can be solved in a tabular format, where column headings are age, root depth, date, pan evaporation, crop factor, daily use, cumulative water use, allowable water use, rainfall, and irrigation, respectively. Values for root depth, crop factor, and allowable water use are computed by age and tabulated. The date and pan evaporation (in millimeters ) values are entered in the table. Pan evaporation is multiplied by the daily crop factor value and the product entered in the daily use column. Daily water use values are cumulated until the cumulative use approximates the allowable water use value, at which time irrigation is applied. Rainfall and irrigation depths are recorded and subtracted from the cumulative water use value on the date of occurrence. We assumed a water application efficiency of $80 \%$, which required an irrigation of 1.2 times the cumulative use on the date of irrigation.

Model validation. A line-source irrigation system as described by Bauder et al. (1975) and Hanks et al. (1976) was used to verify the snap bean irrigation scheduling model in 1985 and 1986. The line-source irrigation system consisted of a single line of closely spaced $(6.1 \mathrm{~m})$ sprinklers to provide uniform water application parallel to the irrigation line and continuously decreasing water application with increasing distance from the irrigation line.

General cultural practices were the same for 1985 and 1986. A rye (Secale cereale L.) covercrop was incorporated to a depth of $15 \mathrm{~cm}$ before moldboard plowing to a depth of $30 \mathrm{~cm}$. Fertilizer at $28 \mathrm{~N}-24 \mathrm{P}-170 \mathrm{~K}\left(\mathrm{~kg} \cdot \mathrm{ha}^{-1}\right)$, respectively, and ethyl(4(methylthio)-m-tolyl isopropylphosphoramidate (phenamiphos, a preplant nematicide) at $6.7 \mathrm{~kg} \cdot \mathrm{ha}^{-1}$ were incorporated to a depth of $10 \mathrm{~cm}$ immediately before seeding. 'Greencrop' snap beans were seeded at $4-\mathrm{cm}$ spacing in rows spaced $0.9 \mathrm{~m}$ apart on 1.8-m beds on 10 Apr. 1985 and 25 Mar. 1986. Immediately after seeding, 2-chloro-N-(2-ethyl-6-methylphenyl)-N-(2-methoxy-1-methylethyl)acetamide (metolachlor, a preemergence herbicide) at $1.6 \mathrm{~kg} \cdot \mathrm{ha}-1$ was applied to the soil surface and incorporated with $13 \mathrm{~mm}$ of irrigation. The $\mathrm{N}$ sidedress was split, with one half applied at expansion of the first trifoliolate leaf and the remainder at expansion of the fourth trifoliolate leaf. Sidedress N rates in 1985 were 20, 30, 40, 50, and 60 $\mathrm{kg} \cdot \mathrm{ha}^{-1}$ at each application to provide $50 \%, 75 \%, 100 \%, 125 \%$, and $150 \%$ of the recommended rate of 78 to $112 \mathrm{~kg} \cdot \mathrm{ha}^{-1}$ total $\mathrm{N}$ (Plank, 1989). Total $\mathrm{N}$ rates in 1986 were 50\%, 100\%, and $150 \%$ of the recommended rate.

The experimental design was a split block with five $\mathrm{N}$ rates and seven irrigation rates in 1985 and three $\mathrm{N}$ rates and seven irrigation rates in 1986. Plots were replicated once on each side of the irrigation line in 1985 and twice on each side of the irrigation line in 1986 . The $\mathrm{N}$ plots were $6.1 \times 14.6 \mathrm{~m}$ with seven irrigation rate plots within each $\mathrm{N}$ plot. The irrigation rate plots were $6.1 \mathrm{~m}$ long and $1.8 \mathrm{~m}$ wide. The beds were parallel to the irrigation line and irrigation rates decreased as distance from the irrigation line increased. The irrigation line was placed on a central guard-bed and the third bed from the line received irrigation according to the model. Depth of water application to each bed on both sides of the irrigation line were measured at each irrigation. Soil water tensions at 150, 300, and $460 \mathrm{~mm}$ in the first, third, fifth, and seventh beds were monitored with cylindrical gypsum block sensors using a Delmhorst Model KS1 meter (Delmhorst Instrument Co., Boonton, N.J.).

Plants from a 2.7- $\mathrm{m}^{2}$ area of each plot were removed, counted, and weighed. Pods were removed and a 1-kg sample was graded to remove nonmarketable pods. Marketable pods were weighed and used for quality and storage analyses.

In $1985,450 \mathrm{~g}$ of marketable pods from each treatment were stored for 10 days at $15 \mathrm{C}, 85 \%$ to $90 \% \mathrm{RH}$. Pods were graded as marketable or nonmarketable based on appearance and were then weighed.

In 1986, surface color of marketable pods was measured with a Gardener XL-20 tri-stimulus calorimeter (Gardner Laboratory, Bethesda, Md.), standardized to reference plate; $\mathrm{L}=92.94$, a $=1.05$ and $\mathrm{b}=0.44$. About 20 pods were formed into $\mathrm{a}$ bundle, secured with masking tape, and both ends of the pods were cut off. These cylinders of pods were stored at $5 \mathrm{C}$ and 95\% $\mathrm{RH}$ for weight loss and brown end discoloration (BED) evaluation after 8 days. BED was scored on a scale of 1 to 5 , where 5 represented no BED and 1 represented severe BED.

Data were tested by regression analyses using the general linear models procedure of SAS (Ray, 1982).

\section{Results and Discussion}

In 1985, the model called for six irrigations and a total depth of $100 \mathrm{~mm}$ (Table 1). The snap beans received a total of 148 $\mathrm{mm}$ of rainfall on seven dates. The line-source irrigation system provided irrigation depths ranging from $3 \%$ to $145 \%$ of the model rate. In 1986, the snap beans intercepted $31 \mathrm{~mm}$ of rainfall, with $22 \mathrm{~mm}$ occurring 49 days from seeding. The model called for 11 irrigations and a total depth of $196 \mathrm{~mm}$ (Table 1). The line-source irrigation system provided irrigation depths ranging from 470 to $180 \%$ of the model.

Soil water tension readings in 1985 were considered unreli-

Table 1. Water application rates to 'Greencrop' snap beans.

\begin{tabular}{|c|c|c|c|c|}
\hline \multirow{2}{*}{$\begin{array}{l}\text { Irrigation } \\
\text { rate }^{z}\end{array}$} & \multicolumn{2}{|c|}{1985} & \multicolumn{2}{|c|}{1986} \\
\hline & $\mathrm{mm}$ & $\%$ of model & $\mathrm{mm}$ & $\%$ of model \\
\hline 1 & 145 & 145 & 354 & 180 \\
\hline 2 & 120 & 120 & 294 & 150 \\
\hline 3 & 100 & 100 & 196 & 100 \\
\hline 4 & 72 & 72 & 156 & 80 \\
\hline 5 & 55 & 55 & 128 & 65 \\
\hline 6 & 38 & 38 & 87 & 44 \\
\hline 7 & 3 & 3 & 8 & 4 \\
\hline Rainfall & 148 & & 31 & \\
\hline
\end{tabular}

${ }^{2}$ All plots received an additional $13 \mathrm{~mm}$ of irrigation after seeding. Irrigation rate 3 was determined by the irrigation scheduling model. Other rates reflect water application gradients produced by the linesource irrigation system. 
able due to frequent malfunctions of the Delmhorst meter; therefore, only data for 1986 are presented (Fig. 1). For a Tifton loamy sand soil having an ASW capacity of $0.1 \mathrm{~cm}^{3}$ per $\mathrm{cm}^{3}$ of soil depth, the allowable soil water deficit (A), calculated as 12.7 (i-4) $\times 0.5 \mathrm{ASW}$, increased $3.8 \mathrm{~mm}$-day 1 until the maximum allowable deficit of $20 \mathrm{~mm}$ was attained 36 days after seeding. The computed cumulative soil water deficit (D) that occurred at the time of each irrigation is also presented in Fig. 1. Cumulative deficit exceeded the allowable deficit by more than $2 \mathrm{~mm}$ on days 39, 47, and 54. The soil water tension (T) at the $15-\mathrm{cm}$ depth remained below $25 \mathrm{kPa}$ until the cumulative deficit exceeded the allowable deficit by $2.6 \mathrm{~mm}$ on day 39 . Excessive deficits of 3.2 and $5.1 \mathrm{~mm}$ on days 47 and 54 resulted in soil water tensions of 46 and $133 \mathrm{kPa}$, respectively. The model showed a deficit of $18 \mathrm{~mm}$ on day 46, at which time the soil water tension at the $15 \mathrm{~cm}$ depth was $18 \mathrm{kPa}$, but irrigation was not applied until day 47 to check snap bean responsiveness to the model. The model called for an irrigation to be applied on day 53, at which time the soil water tension, at the $15-\mathrm{cm}$ depth was $34 \mathrm{kPa}$; however, high wind necessitated a 1-day delay of irrigation to assure a uniform water application gradient with the line-source system. These results and soil water tensions of 22 and $23 \mathrm{kPa}$ when irrigation was applied with 20and $18-\mathrm{mm}$ deficits on days 43 and 59 indicate that the model was effective in maintaining the soil water tension at the $15-\mathrm{cm}$ soil depth below $25 \mathrm{kPa}$ when model conditions were met. A soil water tension of $25 \mathrm{kPa}$ at the $15-\mathrm{cm}$ soil depth was exceeded with water application at $180 \%$ of the model rate only with the delayed irrigation on day 54 . The soil water tension exceeded $25 \mathrm{kPa}$ at $15 \mathrm{~cm}$ at all irrigations with $65 \%$ or less of the model rate.

In 1985 , total plant weight increased as the irrigation rate increased up to $100 \%$ of the model, then changed very little with greater rates of water application (Table 2). Total and marketable pod yield decreased when irrigation was applied at rates less than the model. Total pod yield showed only a slight increase at water application rates greater than the model. Water application rates greater than the model increased lodging of the plants and increased the amount of nonmarketable pods due to decay. Water application rates substantially less than the model also increased the percentage of nonmarketable pods due to nonuniform pod development.

In 1986, total plant weight, total pod yield, and marketable pod yield decreased when water application rates were either greater or less than the model rate (Table 2). The greater responsiveness to deficit and excessive water applications in 1986 as compared to 1985 was attributed to differences in rainfall. Total water intercepted by the snap beans in 1985 ranged from $63 \%$ to $117 \%$ of the model, whereas total water intercepted by the snap beans in 1986 ranged from $22 \%$ to $166 \%$ of the model. These results indicate that the model was relatively accurate in producing high snap bean yields under varying rainfall conditions.

In 1985, storage life, expressed as percentage of marketable pods after 10 days at $15 \mathrm{C}$ and $85 \%$ to $90 \% \mathrm{RH}$, was not affected by irrigation rate or $\mathrm{N}$ fertilization rate. Air circulation around the small sample was very good, and no visible decay of the pods occurred during the 10 days of storage.

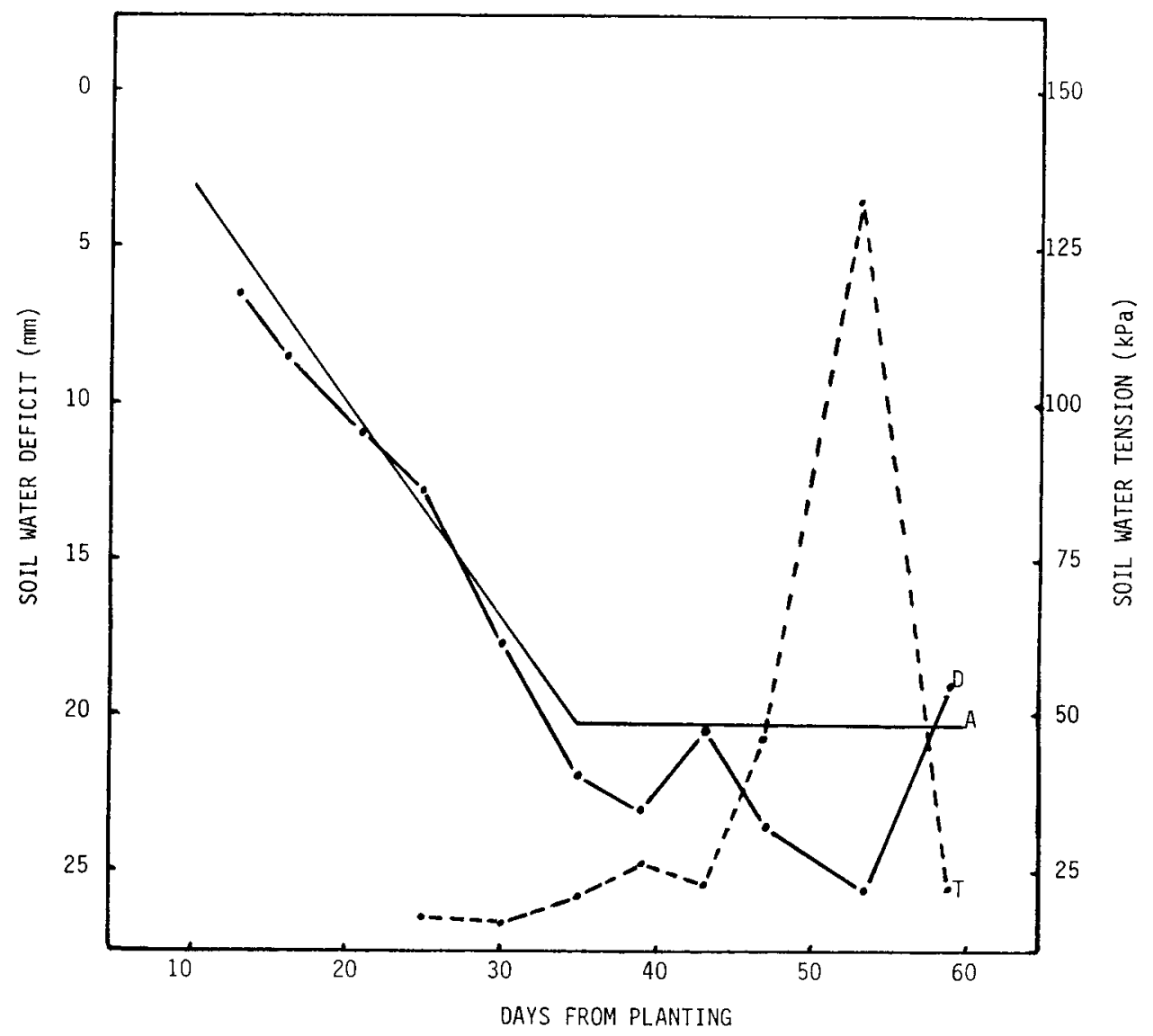

Fig. 1. Allowable soil water deficit (A), soil water deficit between irrigations (D) and soil water tension at 15-cm depth (T) of 'Greencrop' snap beans irrigated according to the irrigation scheduling model (1986). 
Table 2. Yield and quality responses of 'Greencrop' snap beans to irrigation rates.

\begin{tabular}{|c|c|c|c|c|c|c|c|c|}
\hline \multirow{3}{*}{$\begin{array}{l}\text { Irrigation } \\
\text { rate }^{\mathbf{z}}\end{array}$} & & & \multicolumn{4}{|c|}{ Pod yield $\left(t \cdot h a^{-1}\right)$} & \multirow{3}{*}{$\begin{array}{l}\text { Weighty } \\
\operatorname{loss}(\%)\end{array}$} & \multirow[b]{3}{*}{ BED $^{y}$} \\
\hline & \multicolumn{2}{|c|}{ Plant wt $\left(t \cdot h a^{-1}\right)$} & \multicolumn{2}{|c|}{ Total } & \multicolumn{2}{|c|}{ Marketable } & & \\
\hline & 1985 & 1986 & 1985 & 1986 & 1985 & 1986 & & \\
\hline 1 & 27.6 & 18.3 & 12.7 & 7.3 & 10.3 & 5.1 & 7.5 & 3.8 \\
\hline 2 & 26.1 & 26.1 & 11.7 & 10.5 & 10.1 & 8.4 & 7.6 & 3.3 \\
\hline 3 & 26.3 & 27.1 & 11.6 & 11.2 & 10.0 & 8.9 & 7.7 & 2.8 \\
\hline 4 & 24.2 & 23.9 & 10.5 & 10.8 & 8.9 & 7.9 & 7.7 & 2.8 \\
\hline 5 & 22.2 & 20.5 & 9.8 & 9.0 & 7.9 & 6.5 & 8.0 & 3.3 \\
\hline 6 & 21.7 & 14.6 & 9.1 & 6.2 & 7.5 & 3.5 & 8.3 & 3.6 \\
\hline 7 & 17.7 & 6.1 & 7.4 & 1.2 & 6.0 & 0.4 & 10.1 & 4.1 \\
\hline Significance ${ }^{\mathbf{x}}$ & $\mathrm{L}^{* *} \mathrm{Q}^{* *}$ & $\mathrm{~L}^{* *} \mathrm{Q}^{* *}$ & $\mathrm{~L}^{* *} \mathrm{Q}^{* *}$ & $\mathrm{~L}^{* *} \mathrm{Q}^{* *}$ & $\mathrm{~L}^{* *} \mathrm{Q}^{* *}$ & $\mathrm{~L}^{* *} \mathrm{Q}^{* *}$ & $Q^{* *}$ & $Q^{* *}$ \\
\hline
\end{tabular}

${ }^{2}$ Irrigation rate 3 was determined by the irrigation scheduling model. Rates 2 and 1 represent progressively greater water applications, and rates $4,5,6$, and 7 represent progressively smaller water applications by a line-source irrigation system (see Table 1 ).

yWeight loss and brown end discoloration (BED) determined after 8 days of 5C storage in 1986. BED ratings are 1 to 5 , where $5=$ none and $1=$ severely discolored.

x Linear $\left(\mathrm{L}^{* *}\right)$ and quadratic $\left(\mathrm{Q}^{* *}\right)$ effects of irrigation rate significant at $P=0.01$.

Decay of the pods during storage was not evident in 1986. Weight loss increased when snap beans received lower rates of irrigation (Table 2). Weight loss of stored snap beans showed a large increase when irrigated at $4 \%$ of the model. Poor seed set occurred in many of the pods from this treatment, resulting in short, nonuniform-diameter pods. The ends of the pods where seeds did not develop were similar to less mature pods that usually exhibit greater weight loss during storage.

Brown end discoloration was greatest when snap beans were irrigated at $80 \%$ to $100 \%$ of the model rate. Henderson et al. (1977) showed that BED was more closely associated with the development of phenolic compounds in the pods as a response to injury than the concentration of total phenolic compounds in the pods at the time of injury. Since an increase in phenolic compounds generally occurs when plants are exposed to stress conditions $>$ the more severe BED occurring when snap beans were irrigated at $80 \%$ and $100 \%$ of the model rate may reflect a greater susceptibility of these pods to the stress occurring when the pods were injured by cutting.

In 1985, an increase in the $\mathrm{N}$ fertilization rate from $50 \%$ of the recommended rate to $150 \%$ of the recommended rate resulted in a significant linear increase in plant weight (Table 3). Pod yields were not significantly affected by $\mathrm{N}$ rates, although

Table 3. Growth and yield responses of 'Greencrop' snap beans to nitrogen fertilization rates.

\begin{tabular}{|c|c|c|c|c|c|c|}
\hline \multirow{3}{*}{$\begin{array}{l}\text { Nitrogen } \\
\text { rate }^{z}\end{array}$} & \multirow{2}{*}{\multicolumn{2}{|c|}{$\begin{array}{c}\text { Plant } \\
\text { wt }\left(\mathrm{t} \cdot \mathrm{ha}^{-1}\right) \\
\end{array}$}} & \multicolumn{4}{|c|}{ Pod yield $\left(\mathrm{t} \cdot \mathrm{ha}^{-1}\right)$} \\
\hline & & & \multicolumn{2}{|c|}{ Total } & \multicolumn{2}{|c|}{ Marketable } \\
\hline & 1985 & 1986 & 1985 & 1986 & 1985 & 1986 \\
\hline 50 & 22.2 & 18.1 & 9.5 & 7.0 & 8.1 & 4.8 \\
\hline 75 & 22.1 & -- & 10.1 & $\ldots$ & 8.6 & -- \\
\hline 100 & 23.0 & 20.2 & 10.5 & 8.5 & 8.9 & 6.1 \\
\hline 125 & 24.6 & -- & 10.8 & -- & 9.2 & $\ldots$ \\
\hline 150 & 26.3 & 20.2 & 11.1 & 8.7 & 9.1 & 6.5 \\
\hline Sionificancey & $\mathrm{T} * *$ & $\mathrm{NS}$ & No & $\mathrm{I} * * \mathrm{O} * *$ & Ns & $I * * \cap * *$ \\
\hline
\end{tabular}

${ }^{2}$ Nitrogen rates represent percentage of the $88 \mathrm{~kg} \cdot \mathrm{ha}^{-1}$ rate recommended for Georgia (Plank, 1989).

yLinear $\left(\mathrm{L}^{* *}\right)$ and quadratic $\left(\mathrm{Q}^{* *}\right)$ effects of nitrogen rate significant at $P=0.01$ or nonsignificant (NS) at $P=0.05$. both total and marketable yields tended to increase with greater rates of $\mathrm{N}$ fertilization.

In 1986, plant weight was not significantly affected by $\mathrm{N}$ fertilization (Table 3). Total and marketable pod yields increased when the $\mathrm{N}$ fertilization was increased. An increase of the $\mathrm{N}$ rate from $50 \%$ to $100 \%$ of the recommended rate increased total pod yield and marketable pod yield by $21 \%$ and $28 \%$, respectively, whereas further increases to $150 \%$ of the recommended $\mathrm{N}$ rate resulted in only $2 \%$ and $6 \%$ increases in total pod yield and marketable pod yield.

In 1985 , the irrigation rate $\times \mathrm{N}$ rate interaction did not significantly affect marketable pod yields, but this interaction was significant at $P=0.05$ in 1986 . Marketable pod yields with all $\mathrm{N}$ rates were maximized by irrigation at the model rate (Fig. 2). These data show that the increased marketable pod yields with increasing $\mathrm{N}$ rates were due primarily to a response to $\mathrm{N}$ fertilization rate when snap beans were irrigated at $80 \%, 100 \%$, and $150 \%$ of the model rate. Increased $\mathrm{N}$ rates resulted in marketable pod yield increases of $0.2,0.1,0.6,2.7,4.4,2.6$, and $1.6 \mathrm{t} \cdot \mathrm{ha}^{-1}$ when irrigation was applied at $4 \%, 44 \%, 65 \%, 80 \%$, $100 \%, 150 \%$, and $180 \%$ of the irrigation model, respectively.

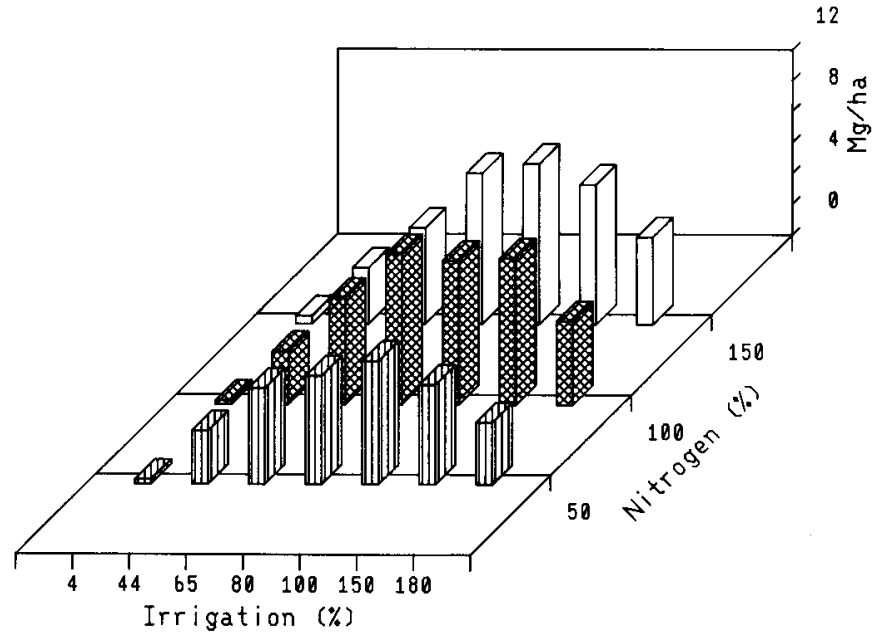

Fig. 2. Effect of irrigation and nitrogen fertilization rates on marketable pod yield of 'Greencrop' snap bean (1986). 
These results are in agreement with an earlier report (Smittle, 1976) that optimization of irrigation increases responsiveness to $\mathrm{N}$ fertilization.

Results of these experiments show that scheduling of the frequency and depth of irrigation can be accomplished effectively with an irrigation scheduling model. Model-based irrigation maximized marketable pod yield in years when rainfall was 31 and $148 \mathrm{~mm}$ during production of the snap bean crop and when $\mathrm{N}$ fertilization rate ranged from $50 \%$ to $150 \%$ of the rate recommended for Georgia.

\section{Literature Cited}

Bauder, J.W., R.J. Hanks, and D.W. Jones. 1975. Crop production function determinations as influenced by irrigation and nitrogen fertilization using a continuous variable design. Soil Sci. Soc. Amer. Proc. 39:1187-1192.

Bonanno, A.R. and H. J. Mack. 1983a. Use of canopy-air temperature differentials as a method for scheduling irrigations in snap beans. J. Amer. Soc. Hort. Sci. 108:826-831.

Bonanno, A.R. and H.J. Mack. 1983b. Yield components and pod quality of snap beans grown under differential irrigation. J. Amer. Soc. Hort. Sci. 108:832-836.

Bruce, R. R., J.L. Chesness, T.C. Keisling, J.E. Pallas, Jr., D.A. Smittle, J. R. Stansell, and A. W. Thomas. 1980. Irrigation of crops in the southeastern United States: Principles and practices. USDA/ SEA Agr. Rev. and Man. ARM-S-9.

Haise, H.R. and R. M. Hagan. 1967. Soil, plant and evaporative measurements as criteria for scheduling irrigation, p. 577-604. In: R.M. Hagan, H.R. Haise, and T.W. Edminster (eds.). Irrigation of agricultural lands. Amer. Sot. Agron., Madison, Wis.

Hanks, R. J., J. Keller, V.P. Rasmussen, and G.D. Wilson. 1976. Line source sprinkler for continuous variable irrigation-crop production studies. Soil Sci. Soc. Amer. Proc. 40:426-429.

Hansen, V.E, O.W. Israelsen, and G.E. Stringham. 1980. Irrigation principles and practices. 4 th ed. Wiley, New York.

Henderson, J. R., R. W. Buescher, and T. E. Forelock. 1977. Influence of genotype and $\mathrm{CO}_{2}$ on discoloration, phenolic content, peroxidase and phenolase activities in snap beans. HortScience 12:453-454.

Jensen, M.E. and J.E. Middleton. 1970. Scheduling irrigation from pan evaporation. Wash. Agr. Expt. Sta. Circ. 527.

Keisling, T., D. Smittle, J. Stansell, and M. Walker. 1975. irrigating for maximum yields. Ga. Agr. Res. 17(1):24-27.

Mack, H.J. and G. W. Varseveld. 1982, Response of bush snap beans (Phaseolus vulgaris L.) to irrigation and plant density. J. Amer. Soc. Hort. Sci. 107:286-290.

Maurer, A.R., D.P. Ormrod, and N. J. Scott. 1969. Effect of five soil water regimes on growth and composition on snap beans. Can. J. Plant Sci. 49:271-278.

Plank, C.O. 1989. Soil test handbook for Georgia. Coop. Ext. Serv., Univ. of Georgia, Athens.

Portas, C.A.M. 1968. Development of root systems during the growth of some vegetable crops. Plant \& Soi1 39:507-518.

Ray, A.A. 1982. SAS users guide: Statistics. 1982 ed. SAS Institute, Cary, N.C.

Singh, B.P. 1989. Irrigation water management for bush snap bean production. HortScience 24:69-70.

Smittle, D.A. 1974. Potential of scheduling irrigation from pan evaporation data. Ga. Agr. Res. 16(2):6-8.

Smittle, D.A. 1976. Response of snap bean to irrigation, nitrogen fertilization, and plant population. J. Amer. Soc. Hort. Sci. 101:3740.

Smittle, D.A. and A. W. Johnson. 1982. Effects of management practices on Meloidogyne incognita and snap bean yield. J. Nematol. 14:63-68.

Stansell, J.R. and D. A. Smittle. 1980. Effects of irrigation regimes on yield and water use of snap bean (Phaseolus vulgaris L.). J. Amer. Soc. Hort. Sci. 105:869-873.

Stegman, E. C., J.R. Musick, and J.I. Stewart. 1980. Irrigation water management, p. 763-816. In: M.E. Jensen (cd.). Design and operation of farm irrigation systems. Amer. Soc. Agr. Eng., St. Joseph, Mich.

Vittum, M.T. and W.J. Flocker. 1967. Vegetable crops, p. 674-686. In: R.M. Hagan, H.R. Haise, and T.W. Edminster (eds.). Irrigation of agricultural lands. Amer. Soc. Agron., Madison, Wis. 